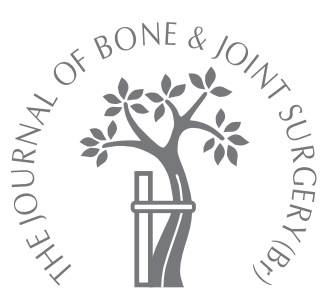

A. W. Davidson, A. Hong, S. W. McCarthy, P. D. Stalley

From The New South Wales Bone and Soft

Tissue Sarcoma Service, The Royal Prince Alfred Hospital, Sydney, Australia

\title{
En-bloc resection, extracorporeal irradiation, and re-implantation in limb salvage for bony malignancies
}

We treated 50 patients with bony malignancy by en-bloc resection, extracorporeal
irradiation with $50 \mathrm{~Gy}$ and re-implantation of the bone segment.

The mean survivor follow-up was 38 months (12 to 92) when 42 patients were alive and without disease. There were four recurrences. The functional results were good according to the Mankin score (17 excellent, 13 good, nine fair, three failures), the Musculoskeletal Tumour Society score (mean 77) and the Toronto Extremity Salvage score (mean 81). There was solid union, but bone resorption was seen in some cases. The dose of radiation was lethal to all cells and produced a dead autograft of perfect fit.

Extracorporeal irradiation is a useful technique for limb salvage when there is reasonable residual bone stock. It allows effective re-attachment of tendons and produces a lasting biological reconstruction. There should be no risk of local recurrence or of radiotherapyinduced malignancy in the replanted bone.

Intra-operative extracorporeal irradiation and re-implantation of the bone segment was first reported by Spira and Lubin ${ }^{1}$ in two patients as a method of limb salvage for bone sarcoma. The dose of radiation is lethal and produces a dead autogenous bone graft of the correct dimensions for re-implantation and reconstruction. There should be no risk of local recurrence and radiotherapy-induced malignancy. ${ }^{2}$ Extracorporeal irradiation was introduced to Australia at our institution in $1996 .^{2}$ We now report the results and complications in our first 50 patients.

\section{Patients and Methods}

Fifty patients with bone malignancy were reviewed, in whom after en-bloc resection, reconstruction had been undertaken by reimplanting the extracorporeal irradiation bone segment. There were 21 pelvic, 17 femoral, 11 humeral and one tibial lesion. These included 21 Ewing's sarcomas, 16 osteosarcomas, ${ }^{3,4} 11$ chondrosarcomas, one metastatic osteosarcoma and one metastatic melanoma.

All the patients with Ewing's sarcoma and osteosarcoma had chemotherapy. In three patients with pelvic lesions post-operative radiotherapy was given because of intralesional resection (case 4) marginal resection (case 43) and contaminated margins (case 48).
There were 23 men and 27 women with a mean age at presentation of 23 years ( 3 to 66 ) and at review of 25 years (6 to 68).

Of the 50 patients eight were either dead or dying. One (case 32) was oncologically clear but had undergone an amputation. She refused to attend and was interviewed by telephone. The remaining 41 were reviewed clinically and radiologically, using the Musculoskeletal Tumour Society score (MTSS), ${ }^{5}$ the Toronto extremity salvage score (TESS) ${ }^{6,7}$ and the score of Mankin et al. ${ }^{8}$ Operative technique. After $e n-b l o c$ resection, the segment is wrapped in a wet sterile drape to minimise air gaps, placed in two sealed sterile plastic bags and wrapped in another sterile drape. This is delivered for radiotherapy. Meanwhile, the operative site is prepared for re-implantation and marginal biopsies taken. On return the specimen is removed from the inner plastic bag and soaked in iodine solution. It is cleared of unnecessary soft tissue leaving important muscle insertions for re-attachment and then re-implanted.

Extracorporeal irradiation. Thirty-two segments were irradiated with 4 to $6 \mathrm{MV}$ photons from a linear accelerator. ${ }^{2,9}$ They were surrounded by water-equivalent materials and irradiated isocentrically with parallel opposed fields. All segments had a single midplane dose of $50 \mathrm{~Gy}$ at a rate of 1.8 to 2.0 Gy per minute. The mean time between the bone segment and returning it to the operating room was 35 minutes. 


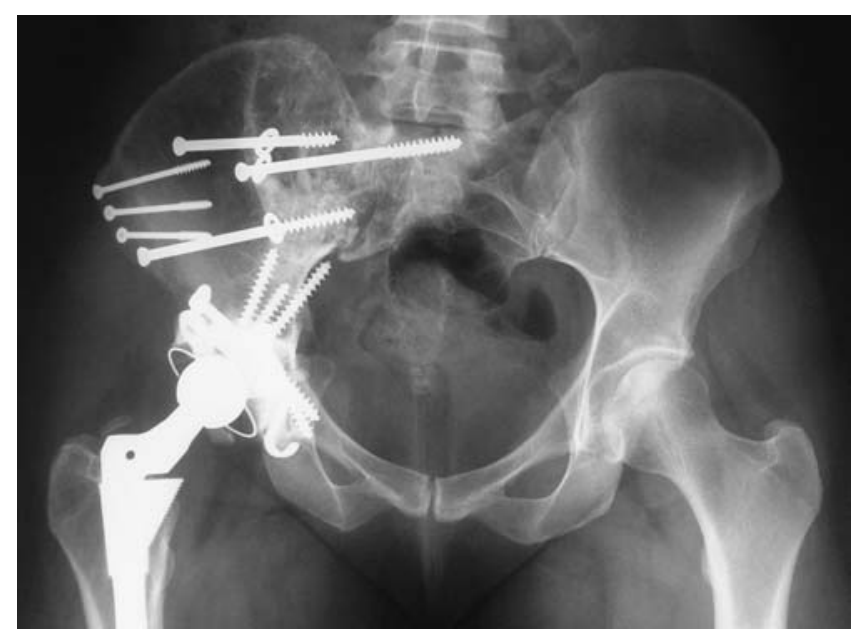

Fig. 1

Radiograph showing pelvic reconstruction with the extracorporeal irradiation-THR composite.

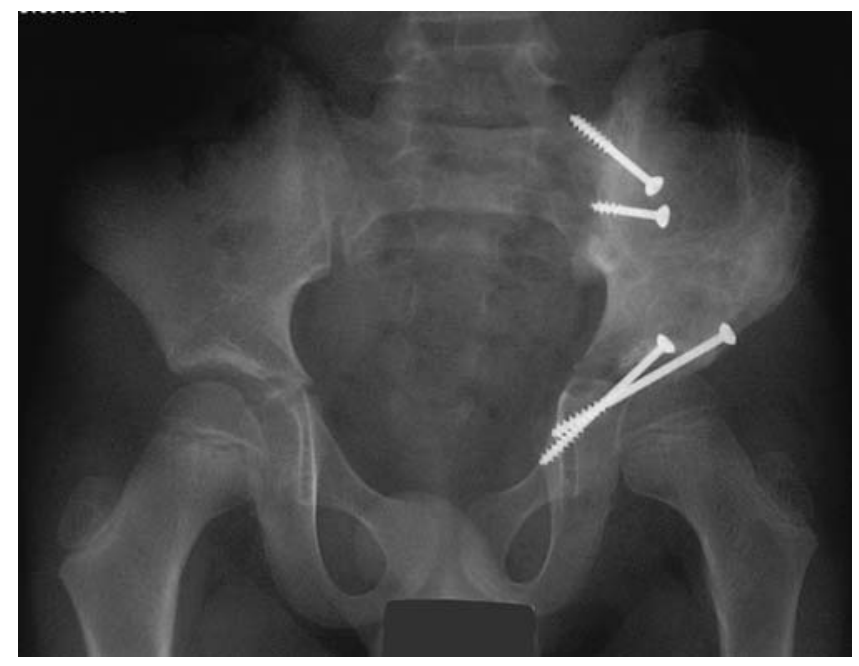

Fig. 2

Radiograph showing pelvic extracorporeal irradiation reconstruction with preservation of the immature femoral head.

Eighteen bone segments measuring less than $19 \mathrm{~cm}$ in length and $12 \mathrm{~cm}$ in thickness were inserted into a cylindrical canister and irradiated in a blood product irradiator (Gammacell 3000 Elan, Nordion, Ontario, Canada). ${ }^{10}$ Each segment was placed in the centre of the canister and water-equivalent material used to fill the remaining space. The dose rate was 4.5 Gy per minute and the mean time from collection to return 20 minutes.

Pelvic reconstruction (21 cases). Total hip replacement (THR) was indicated in 13 skeletally mature patients in whom resection included the acetabulum (Fig. 1). ${ }^{11} \mathrm{~A}$ support ring with a cemented polyethylene acetabular cup and an S-

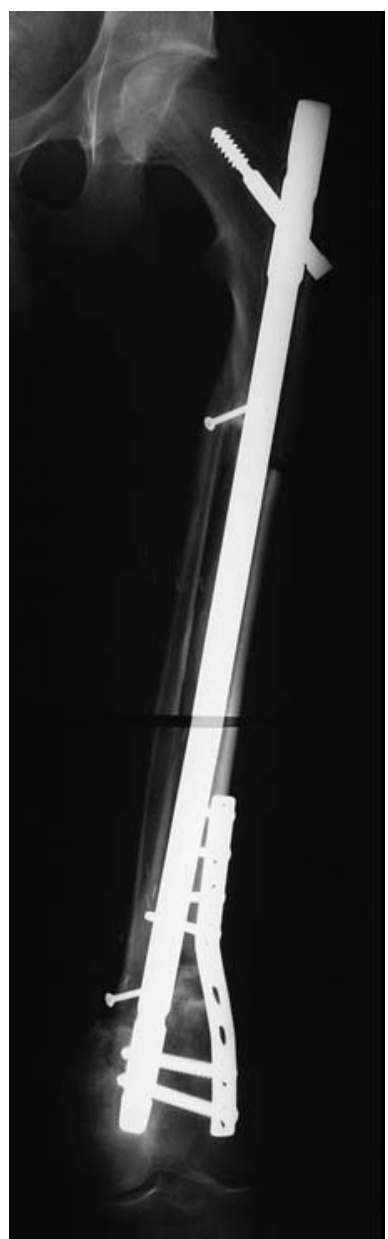

Fig. 3

Radiograph showing femoral extracorporeal irradiation reconstruction.
ROM femoral stem (DePuy, Warsaw, Indiana) with a 28 $\mathrm{mm}$ metal head were used after re-implantation and fixation of the pelvis. In four skeletally immature patients, the femoral head was returned to the acetabulum to preserve the natural joint and proximal femoral growth plate (Fig. 2).

Femoral reconstruction (17 cases). Intercalary resection was performed when possible with stabilisation of the extracorporeal irradiation graft by a nail or plate. Eleven of 14 such patients had a vascularised fibular graft. This was added to the extracorporeal irradiation graft either in parallel (Fig. 3 ) or into a trench (Figs 4 and 5). In two patients in whom the proximal femur had been resected and the abductors preserved, the limb was reconstructed by an extracorporeal irradiation graft and S-ROM THR composite, attaching the abductors to their tendon stumps and stabilising the distal osteotomy by a plate (Fig. 6).

Tibial reconstruction (One case). In one patient (case 2) a diaphyseal chondrosarcoma was treated by intercalary 


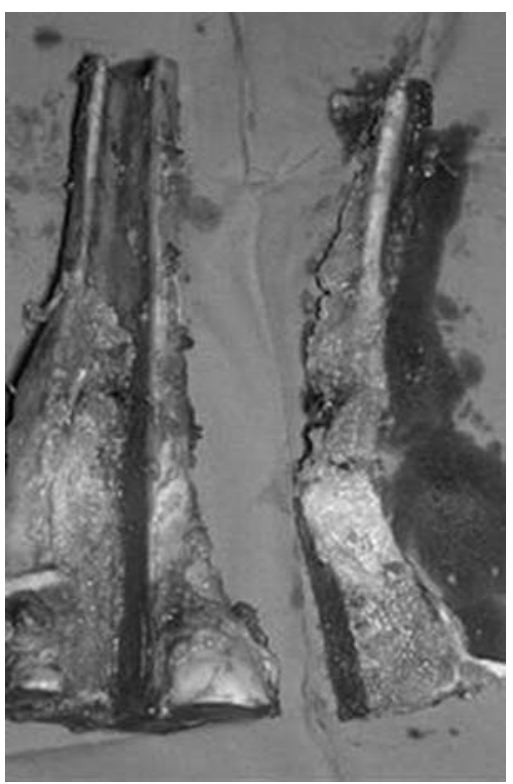

Fig. 4

Photograph showing femoral extracorporeal irradiation graft with a trench cut for a vascularised fibular graft.

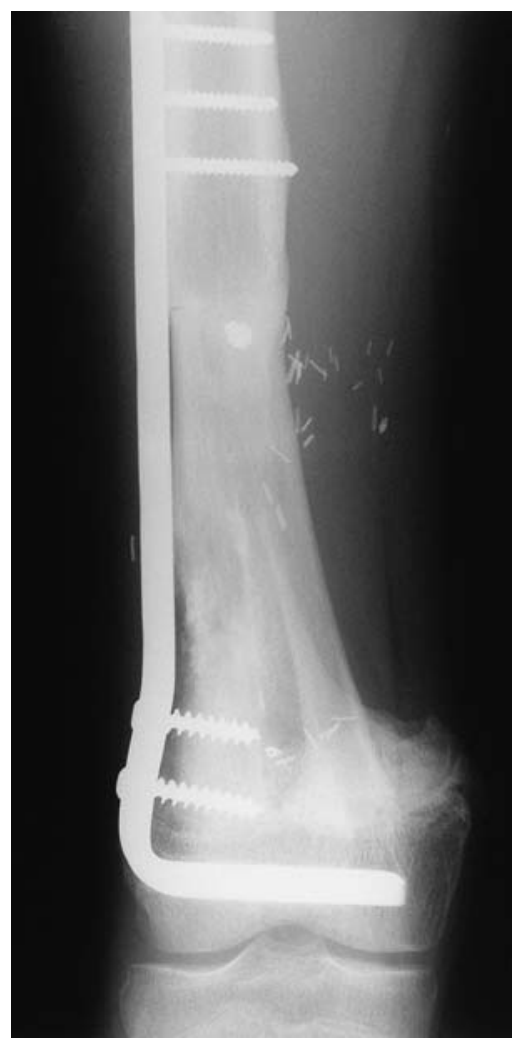

Fig. 5

Radiograph showing femoral extracorporeal irradiation reconstruction with a vascularised fibular graft.

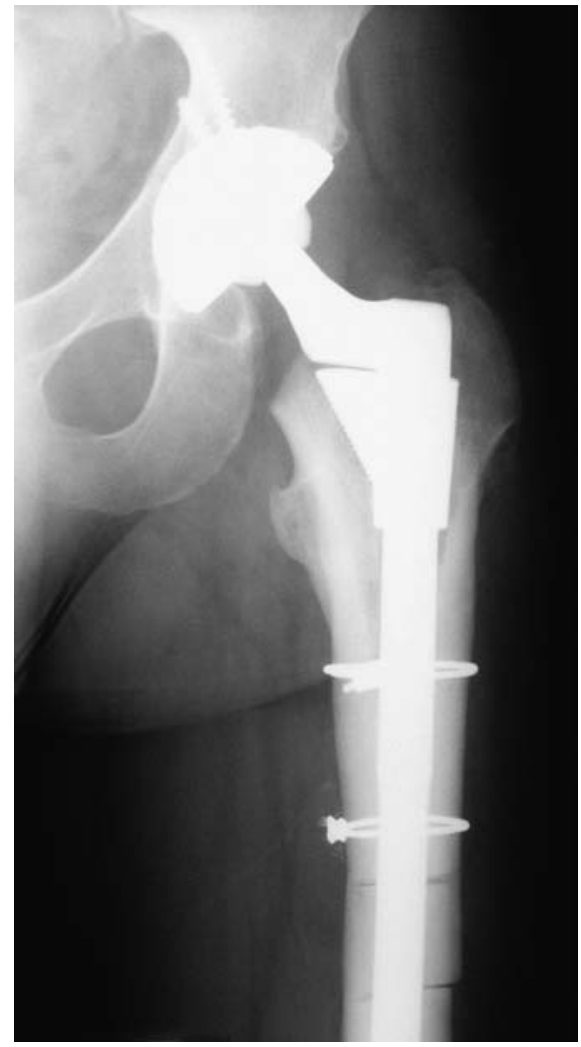

Fig. 6

Radiograph showing proximal femoral reconstruction with the extracorporeal irradiation-THR composite.

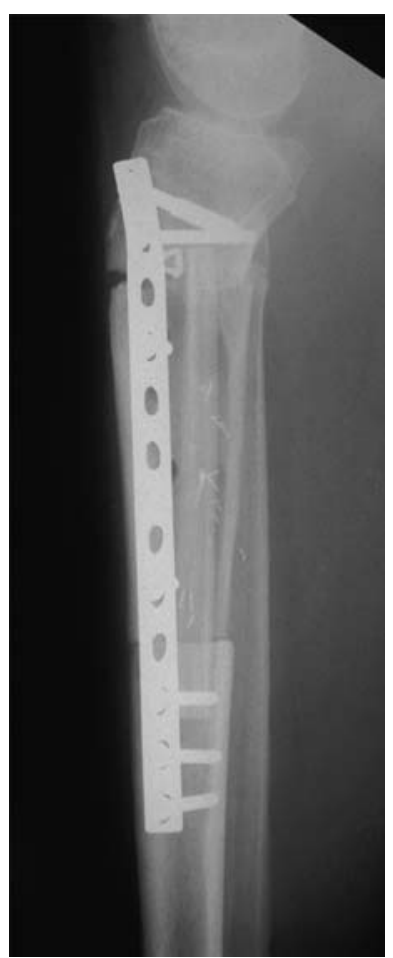

Fig. 7

Radiograph showing tibial extracorporeal irradiation reconstruction with a vascularised fibular graft. 


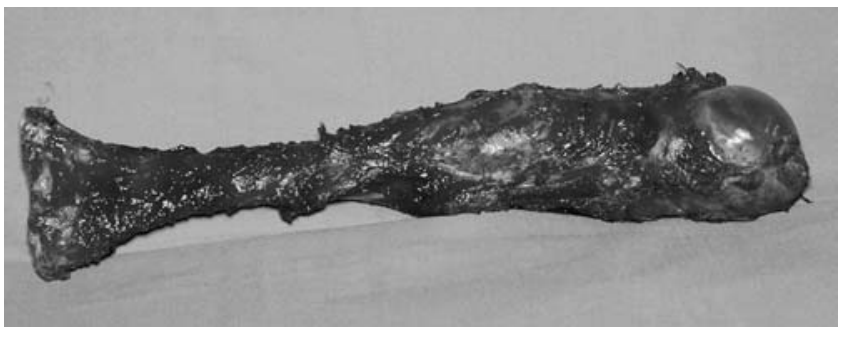

Fig. 8

Photograph showing a humeral extracorporeal irradiation graft.

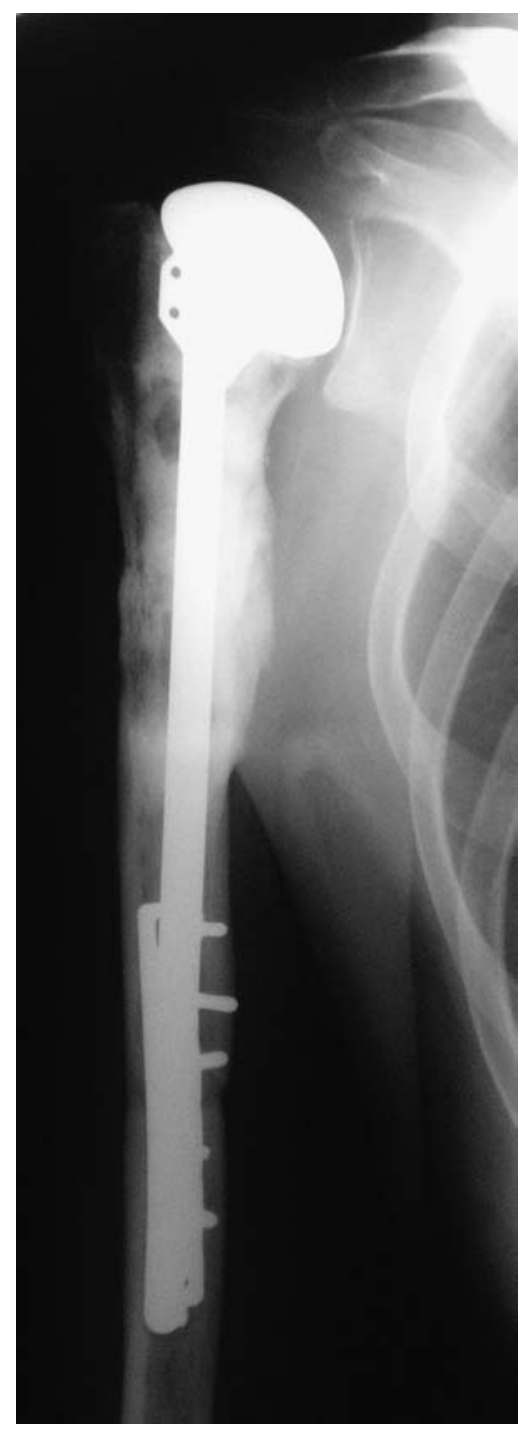

Fig. 9

Radiograph showing a humeral reconstruction with an extracorporeal irradiation-Bigliani shoulder composite.

resection, ECI and re-implantation, combined with a vascularised fibular graft and stabilised by a plate (Fig. 7).

Humeral reconstruction (11 cases). When en-bloc resection of the proximal humerus was performed (Fig. 8) the

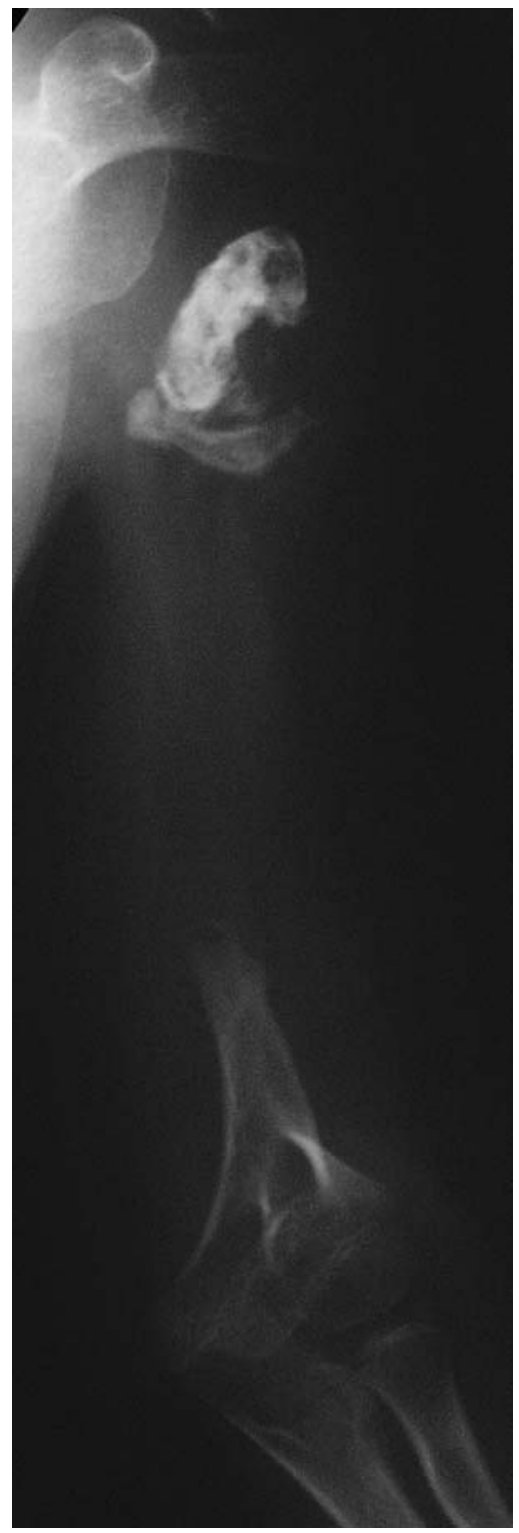

Fig. 10

Radiograph showing dissolution of the humeral extracorporeal irradiation graft.

humeral head was replaced by a cemented long-stem Bigliani prosthesis (Fig. 9) before re-implantation of the graftprosthesis composite. This was because in the first two cases ( 8 and 10) there was dissolution of the humeral head (Fig. 10). The eight proximal humeral cases thereafter had reconstruction by an extracorporeal irradiation graft-prosthesis composite. In one further case an intercalary resection/reconstruction with an extracorporeal irradiationvascularised fibular graft composite was performed.

\section{Results}

The mean survivor follow-up was 38 months (12 to 92), measured from the date of surgery. The results are summarised in Table I which includes the significant incidence 
Table I. Details and results in the 50 patients

\begin{tabular}{|c|c|c|c|c|c|c|c|c|c|c|}
\hline Case & $\begin{array}{l}\text { Age at } \\
\text { onset } \\
\text { (yrs) }\end{array}$ & Bone & $\begin{array}{l}\text { Resection + } \\
\text { reconstruc- } \\
\text { tion }\end{array}$ & Diagnosis & $\begin{array}{l}\text { Survival } \\
\text { (mths) }\end{array}$ & $\begin{array}{l}\text { Mankin } \\
\text { score }\end{array}$ & $\begin{array}{l}\text { MTSS* } \\
\text { score }\end{array}$ & $\begin{array}{l}\text { TESSt } \\
\text { score }\end{array}$ & Complications $¥$ & Re-operations \\
\hline 1 & 6 & Pelvic & $\mathrm{P} 1,2$ & Ewing's sarcoma & 92 & Excellent & 97 & 90 & & \\
\hline 2 & 37 & Tibia & Intercalary & Chondrosarcoma & 87 & Excellent & 93 & 98 & DVT & \\
\hline 3 & 13 & Femur & Intercalary & Ewing's sarcoma & 84 & Excellent & 93 & 100 & Femoral nail breakage & Revision femoral nail \\
\hline 4 & 34 & Pelvis & $\mathrm{S}, \mathrm{P} 1$ & Ewing's sarcoma & Dead & & & & & \\
\hline 5 & 16 & Femur & Intercalary & Ewing's sarcoma & 69 & Good & 80 & 71 & $\begin{array}{l}\text { FHL contracture } \\
\text { Tibial shaft fracture }\end{array}$ & Tibial nail \\
\hline 6 & 14 & Femur & Intercalary & Osteosarcoma & 67 & Excellent & 100 & 96 & & \\
\hline 7 & 17 & Femur & THR & Ewing's sarcoma & 65 & Fair & 50 & 67 & Nonunion & $\begin{array}{l}\text { Graft + plating of } \\
\text { nonunion }\end{array}$ \\
\hline 8 & 3 & Humerus & Proximal & Osteosarcoma & 64 & Failure & 67 & 89 & $\begin{array}{l}\text { Complete graft } \\
\text { resorption }\end{array}$ & \\
\hline 9 & 12 & Femur & Intercalary & Ewing's sarcoma & 59 & Excellent & 90 & 93 & Nonunion & $\begin{array}{l}\text { Removal of distal } \\
\text { locking screws } \\
\text { Graft }+ \text { plating of } \\
\text { nonunion }\end{array}$ \\
\hline 10 & 14 & Humerus & Proximal & Osteosarcoma & 60 & Fair & 67 & 83 & AVN humeral head & \\
\hline 11 & 29 & Femur & Intercalary & Osteosarcoma & 58 & Excellent & 97 & 92 & Nonunion & $\begin{array}{l}\text { Removal of distal } \\
\text { locking screws }\end{array}$ \\
\hline 12 & 21 & Pelvis & $\mathrm{S}, \mathrm{P} 1$ & Ewing's sarcoma & 53 & Good & 67 & 88 & $\begin{array}{l}\text { Wound infection } \\
\text { Minor osteolysis at } \\
\text { iliac crest under plate }\end{array}$ & \\
\hline 13 & 13 & Pelvis & $\mathrm{P} 2,3$ & Ewing's sarcoma & 52 & Excellent & 97 & 95 & $\begin{array}{l}\text { Osteolysis at pubic } \\
\text { symphysis }\end{array}$ & \\
\hline 14 & 10 & Pelvis & $\mathrm{P} 1,2$ & Ewing's sarcoma & 50 & Fair & 60 & 69 & $\begin{array}{l}4 \mathrm{~cm} \text { leg-length } \\
\text { discrepancy }\end{array}$ & \\
\hline 15 & 15 & Pelvis & $\mathrm{P} 1,2$ & Ewing's sarcoma & Dead & & & & & \\
\hline 16 & 46 & Pelvis & P2, 3 & Chondrosarcoma & Dead & & & & & \\
\hline 17 & 39 & Pelvis & $\mathrm{P} 2$ & Chondrosarcoma & 46 & Fair & 50 & 76 & Sciatic nerve palsy & \\
\hline 18 & 11 & pelvis & $\mathrm{P} 1,2$ & Ewing's sarcoma & 47 & Excellent & 90 & 97 & $\begin{array}{l}\text { Wound infection } \\
\text { Peri-acetabular } \\
\text { osteolysis }\end{array}$ & \\
\hline 19 & 9 & Femur & Intercalary & Osteosarcoma & 44 & Excellent & 97 & 98 & & \\
\hline 20 & 15 & Humerus & Proximal & Osteosarcoma & Dead & & & & & \\
\hline 21 & 12 & Femur & Intercalary & Osteosarcoma & 42 & Excellent & 93 & 93 & & Epiphysiodesis \\
\hline 22 & 56 & Femur & Intercalary & Chondrosarcoma & 36 & Excellent & 93 & 91 & & \\
\hline 23 & 16 & Femur & Intercalary & Osteosarcoma & 37 & Excellent & 100 & 96 & & \\
\hline 24 & 55 & Pelvis & $\mathrm{P} 2$ & Chondrosarcoma & Dead & & & & & \\
\hline 25 & 17 & Femur & Intercalary & Ewing's sarcoma & 33 & Excellent & 100 & 100 & Nonunion & $\begin{array}{l}\text { Graft + plating of } \\
\text { nonunion }\end{array}$ \\
\hline 26 & 66 & Pelvis & $\mathrm{P} 1,2$ & Chondrosarcoma & 33 & Good & 73 & 82 & IPR stress fracture & \\
\hline 27 & 14 & Femur & $\begin{array}{l}\text { Lateral fem- } \\
\text { oral condyle }\end{array}$ & Osteosarcoma & 33 & Excellent & 87 & 92 & $\begin{array}{l}2 \mathrm{~cm} \text { short + valgus } \\
\text { deformity }\end{array}$ & Varus osteotomy \\
\hline 28 & 59 & Pelvis & $\mathrm{P} 1,2,3$ & Chondrosarcoma & 32 & Good & 90 & 72 & & \\
\hline 29 & 21 & Pelvis & $\mathrm{P} 2,3$ & Ewing's sarcoma & 30 & Fair & 67 & 81 & $\begin{array}{l}\text { Acetabular osteolysis, } \\
\text { nonunion and } \\
\text { displacement }\end{array}$ & $\begin{array}{l}\text { Revision of acetabu- } \\
\text { lar component } \\
\text { planned }\end{array}$ \\
\hline 30 & 13 & Pelvis & $\mathrm{S}, \mathrm{P} 1$ & Ewing's sarcoma & 29 & Excellent & 86 & 87 & & \\
\hline 31 & 38 & Humerus & Proximal & Osteosarcoma & 27 & Fair & 63 & 48 & Nonunion & Graft + plate \\
\hline 32 & 15 & Humerus & Proximal & Osteosarcoma & 26 & Failure & \multicolumn{2}{|c|}{ Disarticulation } & SRN paraesthesiae & \\
\hline 33 & 10 & Femur & Intercalary & Osteosarcoma & 27 & Good & 77 & 86 & $\begin{array}{l}\text { Nonunion } \\
\text { Stress fracture }\end{array}$ & Graft + plate \\
\hline 34 & 18 & Femur & Intercalary & Ewing's sarcoma & 26 & Excellent & 93 & 94 & $\begin{array}{l}\text { Nonunion } \\
\text { Failure of metalwork }\end{array}$ & $\begin{array}{l}\text { Removal of distal } \\
\text { locking screws } \\
\text { Revision and fixation }\end{array}$ \\
\hline 35 & 17 & Humerus & Intercalary & Chondrosarcoma & 26 & Good & 97 & 99 & $\begin{array}{l}\text { Wound infection } \\
\text { Asymptomatic } \\
\text { nonunion }\end{array}$ & $\begin{array}{l}\text { Wound debridement } \\
\text { Graft planned }\end{array}$ \\
\hline 36 & 53 & Pelvis & P2 & $\begin{array}{l}\text { Metastatic } \\
\text { melanoma }\end{array}$ & 24 & Good & 80 & 80 & - & \\
\hline 37 & 37 & Humerus & Proximal & Osteosarcoma & 25 & Fair & 50 & 50 & & \\
\hline 38 & 17 & Humerus & Proximal & Osteosarcoma & 22 & Good & 73 & 85 & & \\
\hline 39 & 58 & Pelvis & $\mathrm{P} 1,2,3$ & Chondrosarcoma & 21 & Fair & 20 & 40 & $\begin{array}{l}\text { Femoral } \mathrm{A}+\mathrm{V} \text { peri- } \\
\text { operative thrombosis }\end{array}$ & Bypass grafting \\
\hline 40 & 28 & Pelvis & $\mathrm{S}, \mathrm{P} 1,2$ & Ewing's sarcoma & 19 & Good & 93 & 74 & & \\
\hline 41 & 7 & Humerus & Proximal & Ewing's sarcoma & 20 & Good & 73 & 76 & Shoulder instability & $\begin{array}{l}\text { Shoulder } \\
\text { stabilisation }\end{array}$ \\
\hline
\end{tabular}

* MTSS, Musculoskeletal Tumour Society score

† TESS, Toronto Extremity Salvage score

‡ DVT, deep-venous thrombosis; AVN, avascular necrosis; FHL, flexor hallucis longus; IPR, inferior pubic reamus; SRN, sensory radial nerve; A, artery;

$V$, vein 
Table I (cont). Details and results in the 50 patients

\begin{tabular}{|c|c|c|c|c|c|c|c|c|c|c|}
\hline Case & $\begin{array}{l}\text { Age at } \\
\text { onset } \\
\text { (yrs) }\end{array}$ & Bone & $\begin{array}{l}\text { Resection + } \\
\text { reconstruc- } \\
\text { tion }\end{array}$ & Diagnosis & $\begin{array}{l}\text { Survival } \\
\text { (mths) }\end{array}$ & $\begin{array}{l}\text { Mankin } \\
\text { score }\end{array}$ & $\begin{array}{l}\text { MTSS* } \\
\text { score }\end{array}$ & $\begin{array}{l}\text { TESSt } \\
\text { score }\end{array}$ & Complications $\ddagger$ & Re-operations \\
\hline 42 & 51 & Humerus & Proximal & Ewing's sarcoma & 18 & Fair & 67 & 62 & $\begin{array}{l}\text { Minor proximal } \\
\text { osteolysis and } \\
\text { erosion of glenoid }\end{array}$ & \\
\hline 43 & 13 & Pelvis & $\mathrm{S}$ & Chondrosarcoma & Dying & Failure & \multicolumn{2}{|c|}{ Paraplegic } & $\begin{array}{l}\text { Post-operative drop } \\
\text { foot }\end{array}$ & \\
\hline 44 & 21 & Pelvis & $\mathrm{P} 1,2$ & Ewing's sarcoma & Dead & & & & & \\
\hline 45 & 8 & Femur & Intercalary & Ewing's sarcoma & 15 & Failure & \multicolumn{2}{|c|}{ Unable to walk } & Failure of fixation & $\begin{array}{l}\text { Revision fixation + } \\
\text { graft planned }\end{array}$ \\
\hline 46 & 28 & Pelvis & $\mathrm{P} 1,2,3$ & $\begin{array}{l}\text { Metastatic } \\
\text { osteosarcoma }\end{array}$ & Dying & Failure & \multicolumn{2}{|c|}{ Acetabulum } & $\begin{array}{l}\text { Failure of acetabular } \\
\text { component }\end{array}$ & \\
\hline 47 & 15 & Femur & THR & Chondrosarcoma & 12 & Excellent & 93 & 98 & & \\
\hline 48 & 13 & Femur & Intercalary & Osteosarcoma & 12 & Good & 73 & 80 & & Epiphysiodesis \\
\hline 49 & 16 & Pelvis & $\mathrm{P} 2,3$ & Ewing's sarcoma & 12 & Good & 80 & 71 & & \\
\hline 50 & 5 & Humerus & Proximal & Osteosarcoma & 12 & Good & 70 & 81 & $\begin{array}{l}\text { Minor osteolysis of } \\
\text { proximal humerus } \\
\text { beneath prosthesis }\end{array}$ & \\
\hline
\end{tabular}

* MTSS, Musculoskeletal Tumour Society score

† TESS, Toronto Extremity Salvage score

‡ DVT, deep-venous thrombosis; AVN, avascular necrosis; FHL, flexor hallucis longus; IPR, inferior pubic reamus; SRN, sensory radial nerve; A, artery; $\mathrm{V}$, vein

of problems and complications which are predictable in such a group of patients.

Of the 50 patients, $42(84 \%)$ are free from disease and eight have died or are dying, of whom seven had high-grade pelvic malignancies. Local recurrence occurred in four patients. Two had differentiated acetabular chondrosarcoma and one a sacral mesenchymal chondrosarcoma (cases 16, 24 and 43). There was one soft-tissue recurrence in a proximal humeral osteosarcoma (case 32), which required disarticulation of the shoulder.

In the 41 disease-free survivors the outcome was generally good. There were 17 excellent, 13 good and nine fair results with two failures according to the Mankin score. The mean values of the MTSS and TESS were 77 (20 to $100)$ and 81 (40 to 100), respectively.

Most patients had solid bony union, but there was considerable osteolysis in several cases, especially humeral cases 8 and 10. Other examples of osteolysis are described in Table I.

\section{Discussion}

Extracorporeal irradiation and re-implantation is a useful, convenient and inexpensive technique. It should act as a bridge for creeping substitution and incorporation thereby providing the chance of a lifelong biological solution. . $^{1,12,13}$ ECI allows re-attachment of muscle tendons and preserves natural joints, thus eliminating the problems of prosthetic wear. In our patients, reliable bony union of osteotomies was observed, although secondary procedures were needed in some cases. When possible, sparing of the growth plate maximised the growth potential.

Currently, 99 cases on the use of extracorporeal irradiation have been reported in the literature from six centres which have used doses of radiation of between 50 and 300 Gy. ${ }^{1,12-19}$ We used a dose of irradiation of 50 Gy which is equivalent to $250 \mathrm{~Gy}$ in the conventional fraction using the linear quadratic model. The dose is immensely higher than that of the standard fractionated external-beam irradiation treatment for bone tumours and should be sufficient to produce a tumour kill of $100 \%$. There should be no risk of local recurrence or of late radiotherapy-induced malignancy. ${ }^{2}$ We believe that higher doses are unnecessary, take longer to administer and may increase detrimental effects to bone. Bone studies have shown a radiation dose-dependent reduction in strength and also suggest reduced revascularisation and osteoconductive properties, thereby increasing the time to union and incorporation..$^{20-23}$

When compared with other methods of limb salvage, there was no evidence of increased rate of recurrence with extracorporeal irradiation in our series or other similar studies. Furthermore, local recurrence has not been reported after extracorporeal irradiation. The functional outcome, while variable, is encouraging when compared with other methods, especially the long-term results in the lower limb. When investigating survival, longer follow-up is required, but to date this has not been lower than expected.

One area of concern is avascular necrosis and resorption of the graft. This complication mainly occurred in the areas furthest from revascularisation, was most dramatic in the humeral head but was also seen in the pelvis. Intercalary reimplantations do well since they are revascularised from both ends. Radiological remodelling of the extracorporeal irradiation graft was limited and suggested that complete replacement with living bone did not occur and there remained a framework of dead bone which needed the longterm support of the metalwork. This is why we recommend vascularised fibular graft to supplement the reconstruction.

Another disadvantage was the lack of material for histopathological analysis of the effect of chemotherapy and of 
the resection margins. We believe that our marginal biopsies are satisfactory for assessing resection. Our oncologists base post-operative chemotherapy and radiotherapy on the clinical and radiological responses and marginal biopsies. However, our rates of recurrence and mortality have not been increased by these disadvantages.

No benefits in any form have been received or will be received from a commercial party related directly or indirectly to the subject of this article.

\section{References}

1. Spira E, Lubin E. Extracorporeal irradiation of bone tumours: a preliminary report. Israel J Med Sci 1968;4:1015-19

2. Hong A, Stevens G, Stalley P, et al. Extracorporeal irradiation for malignant bone tumours. Int J Radiat Oncol Biol Phys 2001;50:441-7.

3. Enneking WF. A system of staging musculoskeletal neoplasms. Clin Orthop 1986;204:9-24

4. Enneking WF, Dunham WK, Gebhardt MC, Malawar M, Pritchard D. A system for the functional evaluation of reconstructive procedures after surgical treatment of tumours of the musculoskeletal system. Clin Orthop 1993;286:241-6.

5. Enneking WF, Spanier SS, Goodman MA. A system for the surgical staging of musculoskeletal sarcoma. Clin Orthop 1980;153:106-20.

6. Davis AM, Bell RS, Badley EN, Yoshida K, Williams JL. Evaluating functional outcome in patients with lower extremity sarcoma. Clin Orthop 1999;358:90-100.

7. Davis AM, Wright JG, Williams JI, et al. Development of a measure of physical function for patients with bone and soft tissue sarcoma. Qual Life Res 1996;5:508-16.

8. Mankin HJ, Gebhardt MC, Jennings LC, Springfield DS, Tomford WW. Long term results of allograft replacement in the management of bone tumours. Clin Orthop 1996;324:86-97.

9. Mondelaers W, Van Laere K, Uyttendaele D. Treatment of primary tumours of bone and cartilage by extracorporeal irradiation with a low energy high power electron linac. Nuclear Instruments Methods in Physics Res 1993;70-B:898-900.

10. Ralston A, Estoesta E, Stevens G, Hong A. Extracorporeal irradiation: novel use of a blood product irradiator. Australias Phys Eng Sci Med 2001;24:59-62.
11. Enneking WF, Dunham WK. Resection and reconstruction for primary neoplasms involving the innominate bone. J Bone Joint Surg [Am] 1978;60-A:731-46.

12. Uyttendaele D, De Schryver A, Claessens H, et al. Limb conservation in primary bone tumors by resection, extracorporeal irradiation and re-implantation. J Bone Joint Surg [Br] 1988;70-B:348-53.

13. Araki N, Myoui A, Kuratsu S, et al. Intra-operative extracorporeal autogenous irradiated bone grafts in tumor surgery. Clin Orthop 1999;368:196-205.

14. Van Laere K, Casier K, Uyttendaele D, et al. Technetium-99m-MDP scintigraphy and long-term follow-up of treated primary malignant bone tumours. J Nucl Med 1998; $39: 1563-9$

15. Yamamoto T, Akisue T, Marui T, Nagira K, Kurosaka M. Osteosarcoma of the distal radius treated by intra-operative extracorporeal irradiation. J Hand Surg [Am] 2002;27:160-4.

16. Chen WM, Huang CK, Chiang CC, Lo WH. Treatment of malignant bone tumours by extracorporeal irradiated autograft-prosthetic composite arthroplasty. J Bone Joint Surg [Br] 2002;84-B:1156-61.

17. Sys G, Uyttendaele D, Poffyn B, Berdonk R, Verstraete L. Extracorporeally irradiated autografts in pelvic reconstruction after malignant tumour resection. Int Orthop 2002;26:174-8.

18. Bohm P, Fritz J, Thiede S, Budach W. Re-implantation of extracorporeal irradiated bone segments in musculoskeletal tumor surgery: clinical experience in eight patients and review of the literature. Langenbecks Arch Surg 2003;387:355-65.

19. Sabo D, Bernd L, Buchner M, et al. Intraoperative extracorporeal irradiation and replantation for local treatment of primary malignant bone tumours. Orthopade 2003; 32:1003-12.

20. Sabo D, Broacai DR, Eble M, Wannenmacher M, Ewerbeck V. Influence of extracorporeal irradiation on the re-integration of autologous grafts of bone and joint: study in a canine model. J Bone Joint Surg [Br]2000;82-B:276-82.

21. Hamer AJ, Strachan JR, Black MM, et al. Biochemical properties of cortical allograft bone using a new method of bone strength measurement: a comparison of fresh, fresh-frozen and irradiated bone. J Bone Joint Surg [Br] 1996;78-B:363-8.

22. Currey JD, Foreman J, Laketic $\mathbf{I}$, et al. Effects of ionizing radiation on the mechanical properties of human bone. J Orthop Res 1997;15:111-17.

23. Voggenreiter G, Ascherl R, Blumel G, Schmit-Neuerburg KP. Extracorporea irradiation and incorporation of bone grafts: autogenic cortical grafts studied in rats. Acta Orthopaedica Scand 1996:67:585-8. 